\title{
Performance evaluation of project management system based on combination of EFQM and QFD
}

\author{
Amin Ahmadi Digehsara ${ }^{a}$, Hassan Rezazadeh ${ }^{b^{*}}$ and Mohamad Soleimani ${ }^{\mathrm{c}}$
}

${ }^{a}$ Department of Industrial Engineering, Sabanci University, Istanbul, Turkey

${ }^{b}$ Department of Industrial Engineering, University of Tabriz, Tabriz, Iran

${ }^{c}$ Project Manager, Iran Aviation Institute, Tehran, Iran

C H R O N I C L E

\section{Article history:}

Received: January 102018

Received in revised format: April

12018

Accepted: April 232018

Available online:

April 242018

Keywords:

PMS

European Foundation for Quality

Management (EFQM)

Quality function deployment

(QFD)

\section{A B S T R A C T}

\begin{abstract}
Project management system (PMS) is broadly recognized as the effective management tool for several organizations. European Foundation of Quality Management (EFQM) model provides some advantages for companies to be successful in current competitive environment. This paper is based on the combination of EFQM and Quality function deployment (QFD) in order to evaluate a PMS in an aviation organization. Although, an integration of these models increases the system complexity, the implementation of EFQM-QFD helps us identify all noteworthy success factors of PMS within the organization. In addition, the current status of PMS performance is evaluated based on these factors. This study attempts to find out how organizations ought to be managed to take full advantage of PMS tools. This study uses a comprehensive questionnaire to find all critical factors influencing on the success of the organization. The method of this paper is implemented in an organization in aviation industry with several management departments.
\end{abstract}

C 2018 by the authors; licensee Growing Science, Canada.

\section{Introduction}

Project management is the application of knowledge, skills, tools, and techniques implemented for the project activities to meet the project requirements. In other words, project management includes activities for planning, organizing, performance supervision and performance guidance, and tries to deliver specified results by proper utilization of resources and with previously agreed upon cost in due time (PMI, 2013).

Nowadays, organizations are facing with various challenges for evaluating their performance. In general, performance means efficiency in addition to flexibility, creativity and continuous improvement. Weaknesses of traditional performance evaluation systems have motivated researchers to find improved approaches to assess the system performance. Therefore, many processes were made to be used in diverse organizations. Table 1 shows a number of evaluation systems (Taticchi et al., 2010).

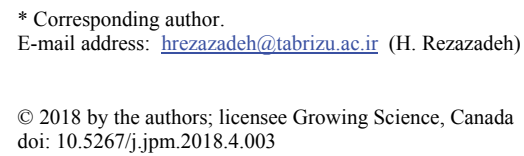




\section{Table 1}

Types of evaluation models and their publication year

\begin{tabular}{lll}
\hline Period & & \multicolumn{1}{c}{ Model (System) } \\
\hline 1988 & Strategic Measurement Analysis and Reporting Technique (SMART) & Cross \& Lynch \\
1989 & Supportive Performance Measures (SPA) & Keegan et al. \\
1990 & Performance Measurement Questionnaire (PMQ) & Dixon et al. \\
1992 & Balanced Scorecard (BSC) & Kaplan \& Norton \\
1995 & Return on Quality Approach (ROQ) & Rust et al. \\
1996 & Cambridge Performance Measurement Framework (CPMF) & Neely \\
1996 & Consistent Performance Measurement System (CPMS) & Flapper et al. \\
2000 & Integrated Performance Measurement System (IPMS) & Bititci et al. \\
2000 & Integrated Performance Measurement Framework (IPMF) & Medori \& Steeple \\
1999 & Business Excellence Model (BEM) & EFQM \\
2000 & Dynamic Performance Measurement System (DPMS) & Bititci et al. \\
2006 & Performance, Development, Growth Benchmarking System & St-Pierre and Delisle \\
\hline
\end{tabular}

PMS can be evaluated by some general methods. The PMS, as a whole system, needs to be evaluated at several parts. The evaluation system can be divided into three general categories. They are discussed in the Table 2.

\section{Table 2}

Different methods of PMS evaluation

\begin{tabular}{lll}
\hline 1 & Quantitative evaluation & $\begin{array}{l}\text { PMS evaluation based on statistical methods } \\
\text { PMS evaluation based on OR (operation research) methods }\end{array}$ \\
2 & Qualitative evaluation & PMS evaluation based on EFQM \& TQM organization excellence standard \\
3 & $\begin{array}{l}\text { Quantitative/Qualitative eval- } \\
\text { uation }\end{array}$ & $\begin{array}{l}\text { PMS evaluation based on PMBOK standard } \\
\text { PMS based on OMP3 organization maturity standard } \\
\text { Evaluation based on dynamic method \& system analysis method }\end{array}$ \\
\hline
\end{tabular}

The most important part of PMS are stakeholders who can significantly influence the project and organizational performance. They are people or organizations practically involved in project system and can have positive or negative effects on project implementation process or accomplishment of the project. Thus, the project management group must identify the stakeholders at the beginning or even during the project, and evaluate their needs and expectations to insure the project success by managing and supervising these needs and expectations. However, categorize the project stakeholders and the factors affecting them are often hard and project management group barely obtain a complete list of project stakeholders. Based on our knowledge, this paper is the first attempt to achieve critical success factors from stakeholder's vision on PMS. Furthermore, we try to present suitable strategies for PMS improvement based on the critical success factors. Previous studies have emphasized on project management which was defined as a point where three goals: time, cost and unique features meet (Atkinson, 1999; Cooke-Davies, 1990; Pinto \& Slevin, 1988). During this period, PMS system was not based on distinctive groups such as stakeholders and most researches were carried out on project management performance evaluation and its multiple effects on project management accomplishment. Kerzner (1987) offered a list of critical success factors in PMS and analyzed the effects of these factors on the stakeholders. Pinto and Slevin (1988) clarified comprehensive list of success factors. The definition of stakeholders during this period was unclear and vague. Morris et al (1987) showed that all stakeholders should be identified through evaluation phase in order to evaluate PMS success. The first research achievement in the relationship between project management and quality management was associated 
with the effect of project management on the successful implementation of total quality management (TQM). Hides (2000) showed that the effective implementation of TQM needs to have accurate PMS. To end with, Davis (2014) investigated the important role of all stakeholders in PMS success. In order to evaluate PMS performance one needs to accomplish a comprehensive framework. ISO, Canadian award for quality and reliability, and National award model for organization excellence and EFQM are different methods to define a frame work. Hillman (1994) introduced National award model for organization excellence and efficiency as the most common method for evaluation of organization improvements. A national award model for organization excellence and efficiency was known as a method in definition of total quality management (European Foundation for Quality Management, 1999). QFD is a prevalent quality technique that is settled design quality to achieve well customer expectations (Sullivan, 1986; Akao, 1990). In QFD procedure, a matrix named the house of quality (HOQ) is used to show the relationship between the CRs and DRs (Hauser \& Clausing, 1988). Yousefie et al. (2011) used EFQM and QFD to select effective management tools.

\section{Preliminary}

\subsection{Project management evaluation model}

The EFQM was established based on a series of fundamental concepts and principles which are necessary for the whole organizational performance (irrespective of organizational size and functions). These concepts consist of result orientation, customer orientation, leadership, stability of aims, reality and process based management, staff participation and development and continuous learning, innovation and improvement, development of partnership and social responsibilities (Eskildsen, 1998; Ghobadian \& Woo, 1996; Westlund, 2001; Wiele et al., 2000). Consequently, EFQM is a suitable model for project management performance evaluation. Bryde (2003) presents six the following criteria as Fig. 1.
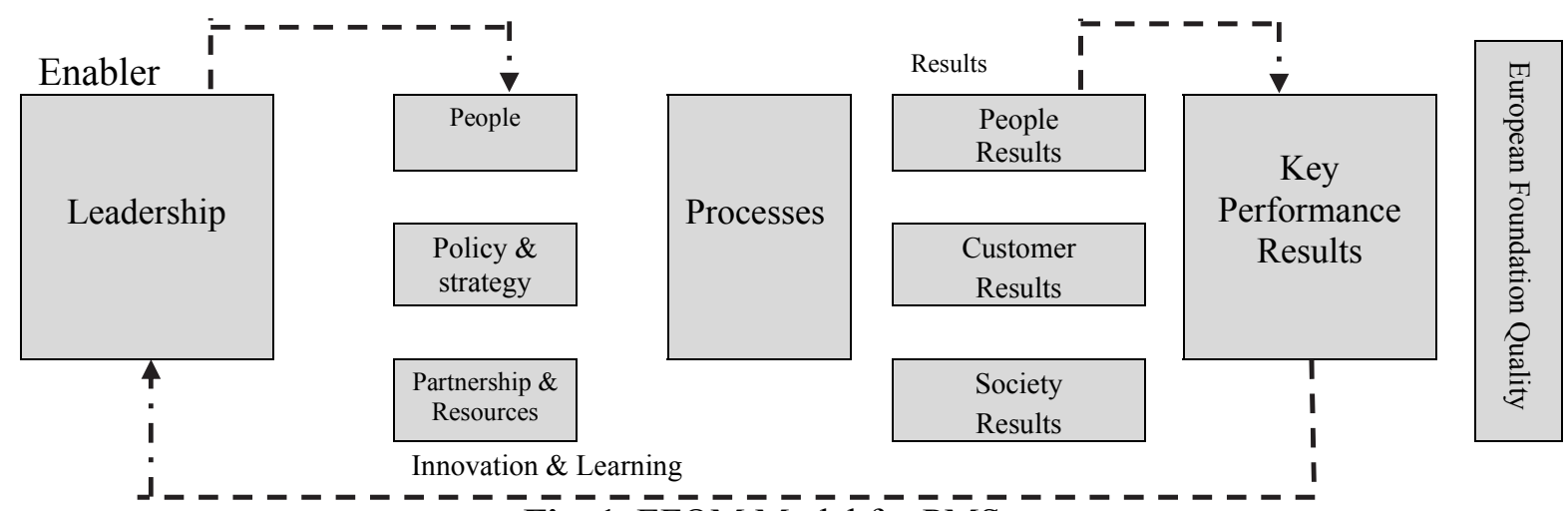

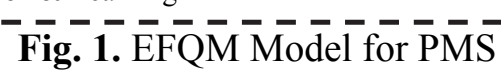

\subsection{Quality Function Deployment}

QFD is structured approach to define customer requirements and translate them into design requirements to produce products with specific needs. The "voice of the customer" describes these specified and unspecified customer requirements. QFD inspects the market and classify customers and attempts to identify customer's needs through analysis of different processes and considers them in all design and production phases. House quality matrix contains useful materials. The rows indicate CRs and the columns show DRs. The cell where each CR and DR meet is specified by $0,1,3$ or 9. As a final point, critical factors from the stakeholders' point of view can be found.

\section{Research methodology and Assumption}

Our suggested methodology can be described in the following five steps:

Step1: Collect PMS elements and evaluate their performances from stakeholders' point of view. 
Step2: Preparation, distribution and statistical analysis of a questionnaire based on the European Foundation for Quality Management excellence model. Each of the nine criteria is evaluated through some questions.

Step 3: Determine the project stakeholders' needs and convert these needs to HOQ matrix. Moreover complete critical success factors based on the stakeholder's standpoint.

Step 4: Define a list of critical success factors according to the organization charts.

Step 5: Determine the effects of success factors in selection of $R \& D$ projects.

\subsection{Critical success factors}

There are three main steps to achieve CR:

Step 1- categorize the responders and determine the importance of each one.

Step 2- collect the questionnaires and determine their importance.

To find the importance of customer demands, initially, the importance of customers' demands by consideration of stakeholders without their correlation are calculated, and then importance of customer demands by consideration of stakeholders are normalized according to Eq. (2), (Maleki et al., 2010).

$$
\begin{aligned}
& D_{i j}=\left(C_{j} \times d_{i j}\right)+\sum_{i}^{I} d_{i^{\prime} j} \times \alpha_{i i^{\prime}} \forall i, j \\
& d^{\text {norm }_{i^{\prime}}=}=\frac{D_{i j}}{\sum_{1}^{I} D_{i j}}
\end{aligned}
$$

Eq. (1) shows the importance of $i$ th factor by $j$ th customer when other factors effect on it. The first term calculates the responder i's importance times to the score given to factor $\mathrm{jth}$. The second term shows the total effects of other factors on ith factor, and Eq. (2) normalizes this value. The above equations yield the matrix of stakeholders' importance. Table 3 shows mathematical symbols definition.

Table 3

\begin{tabular}{|c|c|c|}
\hline No. & Symbol & Concept \\
\hline 1 & I & Number of collected demands of stakeholders \\
\hline 2 & $\mathrm{~d}_{\mathrm{i}}$ & $\begin{array}{l}\text { Importance of stakeholders' demands disregarding the correlation and the importance of the } \\
\text { responder }\end{array}$ \\
\hline 3 & $\mathrm{a}_{\mathrm{ii}}{ }^{\prime}$ & Correlation between $\mathrm{i}^{\text {th }}$ and $\mathrm{i}^{\text {'th }}$ demand \\
\hline 4 & $\mathrm{D}_{\mathrm{ij}}$ & Importance of responders' demands regarding the correlation and importance of responder \\
\hline 5 & $d^{\text {norm }_{i^{\prime}}}$ & Normalized importance \\
\hline 6 & $\mathrm{C}_{\mathrm{j}}$ & Importance of $\mathrm{j}^{\text {th }}$ customer \\
\hline
\end{tabular}

Concept of mathematical symbols

When normalized scores per stakeholders' are calculated, twenty demands with the maximum weights are selected and considered as CR's for the first house of quality.

Step 3- Determine the target values for each DR of the matrix and develope a model for maximizing the stakeholders' satisfaction by considering positive or negative correlation between their needs. 
It is clear that increase or decrease in one of the DRs will change the other DRs. Thus, the value of these correlations are specified by signs. In some cases, the specifications have an inverse relationship which means if one of them is considered at a high level, the other one will be ignored. In such cases, making a sort of balance or tradeoff between the specifications is easy. In addition, if both specifications are accessible at high level, indeed, the customer satisfaction is high. Finally, determine importance of qualitative characteristics in order to identify the most important of them. The following steps are suggested to compute the importance of each qualitative characteristic:

- Determine the degree of relationship between customer's demands and operational characteristics

- Determine the degree of correlation between operational characteristics

- Normalize the values of relationship degrees: to normalize values, in case of a correlation between the characteristics, use the following terms (Maleki et al., 2010).

$$
\begin{aligned}
R^{\prime}{ }_{i k} & =\frac{\sum_{k^{\prime}=1}^{K} R_{i k^{\prime}} \times \beta_{k k^{\prime}}}{\sum_{k=1}^{K} \sum_{k^{\prime}=1}^{K} R_{i k^{\prime}} \times \beta_{k k^{\prime}}} \forall i, k \\
W_{k} & =\sum_{i=1}^{n} d_{i}^{\prime n o r m} \times R_{i k}^{n o r m} \forall k \\
W_{k}^{\prime} & =\frac{W_{k}}{\sum_{k=1}^{K} W_{k}}
\end{aligned}
$$

\section{Table 4}

Concept of mathematical symbols

\begin{tabular}{lll}
\hline No. & \multicolumn{1}{l}{ Mathematical Symbol } & Concept \\
\hline 1 & $\mathrm{R}_{\mathrm{ik}}$ & Relationship between customers' $\mathrm{i}^{\text {th }}$ demand andk ${ }^{\text {th }}$ operational characteristics \\
2 & $\mathrm{~B}_{\mathrm{kk}^{\prime}}$ & Correlation between $\mathrm{k}$ and $\mathrm{k}^{\text {th }}$ operational characteristics \\
3 & $\mathrm{R}^{\prime} \mathrm{ik}$ & Normalized importance between stakeholder's $\mathrm{i}^{\text {th }}$ demand and $\mathrm{k}^{\text {th }}$ operational characteristic \\
4 & $\mathrm{~W}_{\mathrm{k}}$ & Absolute importance of $\mathrm{k}^{\text {th }}$ operational characteristic \\
5 & $\mathrm{~W}_{\mathrm{k}}^{\prime}$ & Relative importance of $\mathrm{k}^{\text {th }}$ operational characteristic \\
\hline
\end{tabular}

\subsection{Importance-performance matrix}

Importance-Performance Analysis (IPA) was presented by Martilla and James (1977). This method helps managers achieve a correct understanding of products and services features and focuses on the features having the extreme effects on customer satisfaction to measure the organization performance for those features. The obtained data from customer assessments will be used to make a matrix in which performance is assigned to the $\mathrm{X}$ axis and importance is assigned to the $\mathrm{Y}$ axis. In this method we have four quarters:

First quarter (major strength): If a feature or criterion is assigned to the first quarter of IPA matrix, it means they evaluate the importance of this criterion as good or suitable.

Second quarter (major weakness): If a feature or criterion is assigned to the Second quarter of IPA matrix, it means they have high importance from customers' point of view, but low performance of the organization.

Third quarter (minor weakness): If a feature or criterion is assigned to the third quarter of IPA matrix, it means low importance from customers' point of view and weak performance of the organization.

Fourth quarter (minor strength): If a feature or criterion is assigned to the third quarter of IPA matrix, it means low importance from customers' point of view, and high performance of the organization. 


\section{Numerical results}

\subsection{Questionnaire analysis}

In this paper due to lack of sufficient information and regarding the usable results, the importance value of responders was supposed to be 1 . The questionnaire contains 60 questions. It was distributed between thirty internal stakeholders. They were public sector managers, administrative managers, strategic managers and members of project groups. The questionnaire has been designed based on principles of European Foundation for Quality Management (EFQM) and the responders have answered to two kinds of questions:

1- Importance of the criterion in the organization,

2- The present status of the criterion in the organization.

The score has been given from 0 to 10 . To conclude, the achieved answers are evaluated by quality matrices.

\subsection{Statistical analyses}

Table 5 shows all the CRs and the scores and Fig. 2 shows the status of each factor schematically. As shown in Fig. 2, when the points get closer to a vertical axis, it needs more attention to the factors that causes dissatisfaction. In other words, all stakeholder's demands whose scores are less than 5 and they are in quarter 2 are the main priorities of organization improvement. Next, these results can be obtained from calculations.

\section{Table 5}

The results obtained for all CRs based on the questionnaire

\begin{tabular}{|c|c|c|c|}
\hline Factor & Question & $\begin{array}{l}\text { Average } \\
\text { score }\end{array}$ & $\begin{array}{l}\text { Average im- } \\
\text { portance }\end{array}$ \\
\hline \multirow{6}{*}{ 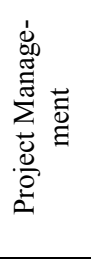 } & The degree to which present senior managers affect PMS performance in the Institute. & 5.34 & 8.31 \\
\hline & $\begin{array}{l}\text { Present staff's planning and management status in managing the projects of the Insti- } \\
\text { tute. }\end{array}$ & 4.86 & 7.445 \\
\hline & Role of the Institute's policies and strategies in PMS performance. & 4.93 & 7.97 \\
\hline & Role of the Institute's policies and strategies in PMS performance. & 4.03 & 6.93 \\
\hline & Status of critical processes in PMS of the Institute. & 4.59 & 7.34 \\
\hline & Role of present key indexes in PMS performance in the Institute. & 4.76 & 7.59 \\
\hline \multirow{11}{*}{ 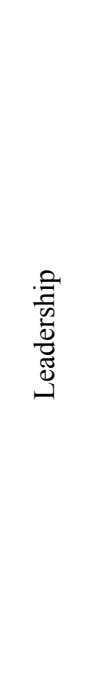 } & $\begin{array}{l}\text { Status of project managers delegating authority to project executive group to manage } \\
\text { the projects of the Institute. }\end{array}$ & 5.17 & 7.66 \\
\hline & $\begin{array}{l}\text { Status of coordination meetings of members of the Institute's projects group for close } \\
\text { physical partnership. }\end{array}$ & 4.31 & 7.41 \\
\hline & $\begin{array}{l}\text { Clear understanding of project stakeholders and employer requirements by executive } \\
\text { managers. }\end{array}$ & 5.24 & 7.66 \\
\hline & $\begin{array}{l}\text { Institutionalization of standards and executive methods by project managers of the In- } \\
\text { stitute. }\end{array}$ & 4.55 & 7.52 \\
\hline & $\begin{array}{l}\text { The degree to which consultant information is used for project management and pre- } \\
\text { senting new ideas. }\end{array}$ & 4.10 & 7.10 \\
\hline & $\begin{array}{l}\text { The degree to which consultant information is used for project management and pre- } \\
\text { senting new ideas. }\end{array}$ & 4.38 & 7.69 \\
\hline & $\begin{array}{l}\text { Motivating the members of project executive groups of the Institute by project man- } \\
\text { ager. }\end{array}$ & 3.59 & 7.83 \\
\hline & Pursuing R\&D projects by senior managers of the Institute. & 4.14 & 7.76 \\
\hline & $\begin{array}{l}\text { The degree to which managers of the Institute are interested in using the Institute re- } \\
\text { sults. }\end{array}$ & 4.69 & 7.59 \\
\hline & Using all potential resources of the Institute for the projects. & 4.69 & 7.45 \\
\hline & The degree to which project monitoring results are practically used by senior managers. & 4.66 & 7.48 \\
\hline
\end{tabular}




\begin{tabular}{|c|c|c|c|}
\hline Factor & Question & $\begin{array}{l}\text { Average } \\
\text { score }\end{array}$ & $\begin{array}{l}\text { Average im- } \\
\text { portance }\end{array}$ \\
\hline \multirow{3}{*}{$\begin{array}{l}\mathscr{E} \\
\stackrel{\pi}{\omega} \\
\sum_{0}^{\infty} \\
\sum_{0}^{\infty}\end{array}$} & $\begin{array}{l}\text { Partnership of different units in implementation of R\&D projects in the Insti- } \\
\text { tute. }\end{array}$ & 4.69 & 7.62 \\
\hline & $\begin{array}{l}\text { The degree to which the projects are in accordance with stakeholders' re- } \\
\text { quirements and the Institute capabilities. }\end{array}$ & 5.21 & 7.45 \\
\hline & $\begin{array}{l}\text { How macro policies of the Institute are announced to executives and contrac- } \\
\text { tors. }\end{array}$ & 4.07 & 7.21 \\
\hline \multirow{13}{*}{ 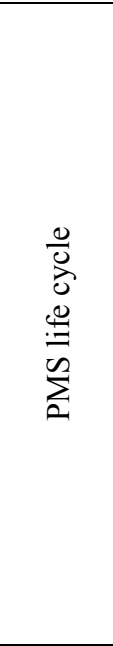 } & Status of information management in PMS of the Institute. & 4.9 & 7.45 \\
\hline & Status of project portfolio management in PMS of the Institute. & 5.1 & 7.66 \\
\hline & $\begin{array}{l}\text { Status of project cost management and control in the Institute by PMS of the } \\
\text { Institute. }\end{array}$ & 5.31 & 7.72 \\
\hline & Status of stakeholder conflict management in PMS of the Institute. & 4.55 & 6.86 \\
\hline & Role of PMS in knowledge management of the Institute's projects & 4.86 & 7.62 \\
\hline & Status of quality management in PMS of the Institute. & 4.72 & 7.48 \\
\hline & Status of change management in PMS of the Institute. & 4.83 & 7.07 \\
\hline & Status of human resource management in PMS of the Institute. & 4.83 & 7.24 \\
\hline & Status of continuous improvement in PMS of the Institute. & 4.93 & 7.24 \\
\hline & Status of scope management in PMS of the Institute. & 4.52 & 7.03 \\
\hline & Status of integration management in PMS of the Institute. & 4.76 & 7.10 \\
\hline & Status of project control in PMS of the Institute. & 5.45 & 7.66 \\
\hline & Status of project planning in PMS of the Institute. & 5.07 & 8.07 \\
\hline \multirow{6}{*}{ 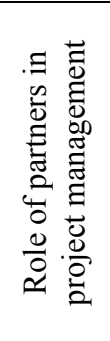 } & Status of two-way dialog with all stakeholders of the Institute. & 4.66 & 6.72 \\
\hline & The degree to which external stakeholders affect PMS of the Institute. & 5.34 & 6.69 \\
\hline & The degree to which internal stakeholders affect PMS of the Institute. & 5.38 & 6.93 \\
\hline & The degree to which financial supporters affect PMS of the Institute. & 5.93 & 7.76 \\
\hline & $\begin{array}{l}\text { The degree to which internal stakeholders are satisfied with PMS of the Insti- } \\
\text { tute. }\end{array}$ & 4.90 & 7.45 \\
\hline & $\begin{array}{l}\text { The degree to which external stakeholders are satisfied with PMS of the In- } \\
\text { stitute. }\end{array}$ & 5.76 & 7.24 \\
\hline
\end{tabular}

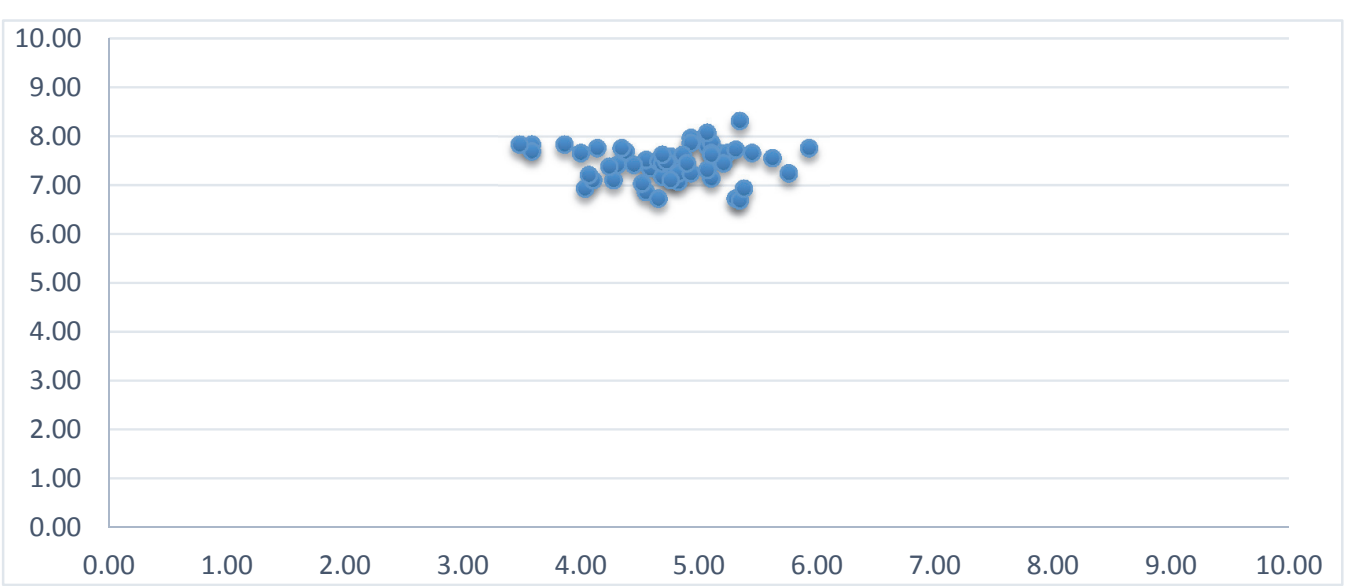

Fig. 2. IPA diagram for all CRs

\subsection{Using quality function deployment (QFD) for evaluations}

The points in the second quarter of Fig. 2 which are extracted from Table 5 (customer demands) can be considered as an equivalent of CR. As a result, in order to satisfy these demands, organization strategies need to be defined. In table 6 , twenty important strategies have been explained. 
Table 6

Strategies of the organization (DR)

\begin{tabular}{ll}
\hline No. & Strategy \\
\hline 1 & Appropriate allocation of capital and property \\
\hline 2 & Effective project group interaction and relation with stakeholders \\
\hline 3 & Paying attention to all key factors of project management (time, cost, scope and quality) \\
\hline 5 & Improving the general knowledge \\
6 & Information system development \\
\hline 7 & Increasing the manpower interest, perseverance and motivation \\
\hline 8 & Creating a two-way dialog between the staff and organization \\
\hline 10 & Planning for improving the human resources \\
\hline 11 & Increasing the staff partnership in the organization issues \\
\hline 12 & Incorporating information and knowledge management \\
\hline 13 & Gratifying the staff \\
\hline 14 & Financial resource management \\
\hline 15 & Leaders interaction with customers and stakeholders \\
\hline 16 & Outsourcing management \\
\hline 17 & Identifying knowledge of the staff \\
\hline 18 & Creating a culture for continuous improvement \\
\hline 19 & Reducing the financial risk \\
\hline
\end{tabular}

House of quality has three sub-matrixes which are defined as below:

a- A matrix dealing with the relation between customer's demands and their effects on each other.

b- A matrix dealing with relation between strategies (DRs) and their effects on each other.

c- A matrix dealing with the relation between customer demands and defined strategies.

Table 7

Strategies obtained from quality matrix

\begin{tabular}{llll}
\hline No. & Strategy & Score & Ranking \\
\hline 1 & Appropriate allocation of capital and property & 37.99 & 20 \\
2 & Effective project group interaction with stakeholders & 81 & 14 \\
3 & Paying attention to all key factors of project management (time, cost, scope and quality) & 69.29 & 18 \\
4 & Improving the general knowledge & 98.15 & 9 \\
5 & Information system development & 95.47 & 11 \\
6 & Increasing the manpower interest, perseverance and motivation & 99.09 & 7 \\
7 & Increasing the learning spirit in the manpower & 108.46 & 5 \\
8 & Creating a two-way dialog between the staff and organization & 98.22 & 8 \\
9 & Planning for improving the human resources & 146.01 & 1 \\
10 & Increasing the staff partnership in the organization issues & 134.40 & 2 \\
11 & Incorporating information and knowledge management & 125.77 & 4 \\
12 & Paying attention to key processes & 96.48 & 10 \\
13 & Gratifying the staff & 72.14 & 17 \\
14 & Financial resource management & 126.11 & 3 \\
15 & Leaders interaction with customers and stakeholders & 91.48 & 13 \\
16 & Outsourcing management & 43.11 & 19 \\
17 & Identifying knowledge of the staff & 101.58 & 6 \\
18 & Creating a culture for continuous improvement & 80.14 & 15 \\
19 & Reducing the financial risk & 79.86 & 16 \\
20 & Technology and method development & 92.96 & 12 \\
\hline & & &
\end{tabular}


Quality function deployment matrix deals with analysis of dependency and effects of customer needs (CRs) as well as dependency and effects of technical needs (DRs). This dependency can be between 3 and +3 . The numbers inside the matrix are $0,1,3$ and 9 based on a scoring system, and after entering the relations, they are as in the annex. Table 7 is the last step of this research and shows the strategy prioritization after analyzing the demands and completing the House of quality matrix. Followed by IPA figure all stakeholders' demands are explained separately for EFQM factors. As shown, all points in second region can be defined as critical factors. In fact, these points express demands which are very important and currently they are defined as weak points in the organization. Also, the points in the first quarter are strong points of the organization which should be kept. Fig. 2 clearly shows that the factors associated with leadership, which are explained in Table 5, are often considered as weak points.

\section{Discussion}

In order to discover the critical factors, all parts of project management investigate through a comprehensive questionnaire. In performance measuring phase, organizations pay much attention to their financial indexes, while financial issue is the only one part of organization performance which is associated with the other factors performances. Moreover, financial indexes mostly indicate the organization performance in the past.

EFQM is formed by two fundamental factors which are "Enablers" and "Results". Terms and concepts incorporated in this model are so general that they can be interpreted in a different way, and organizations can make diverse evaluation indexes with these terms. Quality function deployment can solve this flaw. The main goal of project management is to keep customers and stakeholders fulfilled, and the main objective of quality is to satisfy customer needs. Therefore, to succeed in keeping different stakeholders satisfied, we should use the quality management concepts.

Various methods can be used to design the questionnaire. In this research, excellence quality management principles is considered as a basis and foundation for making the questionnaire. Table 8 shows the normalized importance average. The numerical value 4.744 of 10 indicates the present status of an organization in the PMS with regard to 7 factors of EFQM. Increasing this value means organization status in the PMS is gaining to improve. It should be noted that each stakeholder demand importance value is based on the demand's effect which is obtained via relation 1.

\section{Table 8}

Organization status investigation after using quality matrix

\begin{tabular}{|c|c|c|c|c|c|c|}
\hline No. & $\begin{array}{l}\text { Role in } \\
\text { EFQM }\end{array}$ & EFQM sheet & Score average & $\begin{array}{l}\text { Importance aver- } \\
\text { age }\end{array}$ & $\begin{array}{l}\text { Score im- } \\
\text { portance }\end{array}$ & Ranking \\
\hline 1 & Enabler & Project management & 4.75 & 0.138 & 0.656 & 4 \\
\hline 2 & Enabler & Leadership & 4.50 & 0.142 & 0.639 & 5 \\
\hline 3 & Enabler & Project management staff & 4.31 & 0.143 & 0.616 & 7 \\
\hline 4 & Results & Key indexes of PMS & 4.59 & 0.146 & 0.670 & 6 \\
\hline 5 & Enabler & Policies \& strategies & 4.86 & 0.145 & 0.705 & 3 \\
\hline 6 & Results & PMS life cycle & 4.89 & 0.141 & 0.689 & 2 \\
\hline \multirow[t]{2}{*}{7} & Enabler & Partners' role in PMS & 5.30 & 0.145 & 0.769 & 1 \\
\hline & & Total & & 1 & 4.744 & \\
\hline
\end{tabular}

Finally, twenty important strategies, which are obtained from quality matrix, are ranked in Table 7 and can be implemented as PMS improvement strategies in the respective organization.

\section{Conclusion}

This research has attempted to use the combination method of European Foundation for Quality Management excellence model and quality function deployment to discover present system critical success factors in the organization, and develops system improvement strategies to select projects. 
According to Evaluating of system, the weak point of PMS is PMS staff, and the strong point of PMS is the effects of factors on one another. This research has shown that the effects of different indexes of EFQM on one another must be considered to discover the weakness and strength of PMS of the organization. Also, implementation of every strategy has simultaneous positive or negative effects on the demands. These effects can be considered by considering QFD principles.

The study raises several issues that could implement in further research. Below, some of these extensions are presented:

1- Fuzzy QFD is one of the important methods in project management discussions. Thus, fuzzy principles can be used to develop project management.

2- Implementation of desired strategies is another development method. Each strategy requires a definite executive method, and then these strategies must be evaluated and controlled.

3- Each responder has a special importance in an organization. Since there was not sufficient information available in this research to obtain the weights, all the weights are considered to be the same. These weights can be assumed to be different in future researches.

4- Balanced score card principles can be an option to develop this method rather than considering EFQM as another evaluation index.

5- Creating a mathematical model by using data covering analysis to evaluate PMS can bring researchers more tangible results.

\section{References}

Akao, Y. (1990). Quality Function Deployment: Integrating Customer Requirements Into Product Design. Taylor \& Francis.

Atkinson, R. (1999). Project management: cost, time and quality, two best guesses and a phenomenon, it's time to accept other success criteria. International Journal of Project Management, 17(6), 337343.

Bititci, U. S., Turner, U., \& Begemann, C. (2000). Dynamics of performance measurement systems. International Journal of Operations \& Production Management, 20(6), 692-704.

Bryde, J. (2003). Modelling project management performance. International journal Quality Reliab Manage, 20(2), 225-229.

Cooke-Davies, T. (1990). Return of the project managers. Management Today. Business Information Management, 119-121.

Cross, K. F., \& Lynch, R. L. (1988). The "SMART" way to define and sustain success. Global Business and Organizational Excellence, 8(1), 23-33.

Davis, K. (2014). Different stakeholder groups and their perceptions of project success. International Journal of Project Management, 189-201.

Dixon, J.R., Nanni, A.J., \& Vollmann, T.E. (1990). The New Performance Challenge: Measuring Operations for World-class Competition. Business One Irwin, Homewood, IL.

Eskildsen, J. K. (1998). Total Identifying the vital few using the European Foundation for Quality Management Model. Quality Management, 9(4/5), 92-95.

Flapper, S.D.P., Fortuin, L., \& Stoop, P.P.M. (1996). Towards consistent performance management systems. International Journal of Operations and Production Management, 18, 604-625.

Ghobadian, A., \& Woo, H. S. (1996). Characteristics, benefits and shortcomings of fourmajor quality awards. International Journal of Quality \& Reliability Management, 13(2), 10-44.

Hauser, J. R., \& Clausing, D. (1988). The house of quality. Harvard Business Review, 66, 63-73.

Hides, M. T. (2000). Facilitating total quality through effective project management. International Journal of Quality \& Reliability Management, 17(407-22).

Hillman, G. P. (1994). Making self-assessment successful. The TQM Magazine, 6(3), 29-31.

Kaplan, R. S., \& Norton, D.P. (1992). The balanced scorecard: Measures that drive performance. Harvard Business Review, (January-February), 71-79. 
Keegan, D. P., Eiler, R. G., \& Jones, C. R. (1989). Are your performance measures obsolete?. Strategic Finance, $70(12), 45$.

Kerzner, H. (1987). In search of excellence in project management. Journal of Systems Managemen, $38(2), 30-40$.

Maleki, A. R., Zohor, A. R., Azar, F. E., Rezaie, K., \& Ebadian, M. (2010). An integrated approach in healthcare system in accordance with QFD/ FMEA. Journal of the Iranian Institute for Health Science Research, 9(2), 117-130.

Martilla, J., \& James, J. (1977). Importance-performance analysis. Journal of Marketing. Journal of Marketing, 41(1), 77-79.

Medori, D., \& Steeple, D. (2000). A framework for auditing and enhancing performance measurement systems. International Journal of Operations \& Production Management, 20(5), 520-533.

Morris, P. W. G., \& Hough, G. H. (1987). the Anatomy of Major Projects: A Study of the Reality of Project Management. John Wiley \& Sons Ltd. Chichester.

Neely, A. (2005). The evolution of performance measurement research: developments in the last decade and a research agenda for the next. International Journal of Operations \& Production Management, 25(12), 1264-1277.

Pinto, J. K., \& Slevin, D. P. (1988). Critical success factors across the project life cycle. Project Management Journal, 19(3), 67-73.

PMI. (2013). A Guide to the Project Management Body of Knowledge (PMBOK Guide) (Fifth ed.): Project Management Institute (PMI).

Rust, R. T., Zahorik, A. J., \& Keiningham, T. L. (1995). Return on quality (ROQ): Making service quality financially accountable. The Journal of Marketing, 59(2), 58-70.

Sullivan, L.P. (1986). Quality function deployment: a system to assure that customer needs drive the product design and production process. Quality Progress, 39-50.

St-Pierre, J., \& Delisle, S. (2006). An expert diagnosis system for the benchmarking of SMEs' performance. Benchmarking: An International Journal, 13(1/2), 106-119.

Taticchi, P., Tonelli, F., \& Cagnazzo, L. (2010). Performance measurement and management: a literature review and a research agenda. Measuring Business Excellence, 14(1), 4-18.

Westlund, A. H. (2001). Measuring environmental impact on society in the EFQM system. Total Quality Management, , 12(1), 125-135.

Wiele, V. d., A., W., A.R.T, \& Dale, B. G. (2000). ISO 9000 series registration to business excellence: the migratory path. Business Process Management, 6(5), 417-427.

Yousefie, S., Mohammadi, M., \& Monfared, J. H. (2011). Selection effective management tools on setting European Foundation for Quality Management (EFQM) model by a quality function deployment (QFD) approach. Expert Systems with Applications, 38(8), 9633-9647.

\section{Appendix}

\begin{tabular}{|c|c|c|c|}
\hline \multicolumn{3}{|c|}{ Costumer Voice } & Costumer Voice \\
\hline $\bar{A}$ & Project management training status in the Institute. & $\mathbf{K}$ & $\begin{array}{l}\text { Quality of evaluation indexes in project management system of the In- } \\
\text { stitute. }\end{array}$ \\
\hline B & $\begin{array}{l}\text { Top executives encouragement system in project manage- } \\
\text { ment system of the Institute. }\end{array}$ & $\mathbf{L}$ & $\begin{array}{l}\text { Status of coordination meetings of members of the Institute's projects } \\
\text { group for close physical partnership. }\end{array}$ \\
\hline $\mathbf{C}$ & $\begin{array}{l}\text { Motivating the members of project executive groups of the } \\
\text { Institute by project manager. }\end{array}$ & M & $\begin{array}{l}\text { Status of stakeholder conflict management in project management sys- } \\
\text { tem of the Institute. }\end{array}$ \\
\hline D & $\begin{array}{l}\text { Role of present key indexes in project management system } \\
\text { performance in the Institute. }\end{array}$ & $\mathbf{N}$ & Pursuing R\&D projects by senior managers of the Institute. \\
\hline $\mathbf{E}$ & $\begin{array}{l}\text { Welfare of the staff working in project management system } \\
\text { of the Institute. }\end{array}$ & $\mathbf{O}$ & Accessibility of project pre-determined targets in the Institute. \\
\hline $\mathbf{F}$ & $\begin{array}{l}\text { The effects of superior ordered policies on project manage- } \\
\text { ment system of the Institute. }\end{array}$ & $\mathbf{P}$ & Status of project implementation feedback reception mechanism. \\
\hline G & $\begin{array}{l}\text { Incorporating the knowledge acquired in training courses in } \\
\text { the Institute projects. }\end{array}$ & Q & $\begin{array}{l}\text { Status of scope management in project management system of the Insti- } \\
\text { tute. }\end{array}$ \\
\hline $\mathbf{H}$ & $\begin{array}{l}\text { The degree to which consultant information is used for pro- } \\
\text { ject management and presenting new ideas. }\end{array}$ & $\mathbf{R}$ & $\begin{array}{l}\text { Proper understanding of project management system of the Institute by } \\
\text { all stakeholders. }\end{array}$ \\
\hline I & $\begin{array}{l}\text { Effects of administration and organization structure of the } \\
\text { Institute on project management system performance. }\end{array}$ & $\mathbf{S}$ & $\begin{array}{l}\text { Institutionalization of standards and executive methods by project man- } \\
\text { agers of the Institute. }\end{array}$ \\
\hline $\mathbf{J}$ & $\begin{array}{l}\text { Status of two-way dialog with all stakeholders of the Insti- } \\
\text { tute. }\end{array}$ & $\mathbf{T}$ & $\begin{array}{l}\text { Status of change management in project management system of the In- } \\
\text { stitute. }\end{array}$ \\
\hline
\end{tabular}



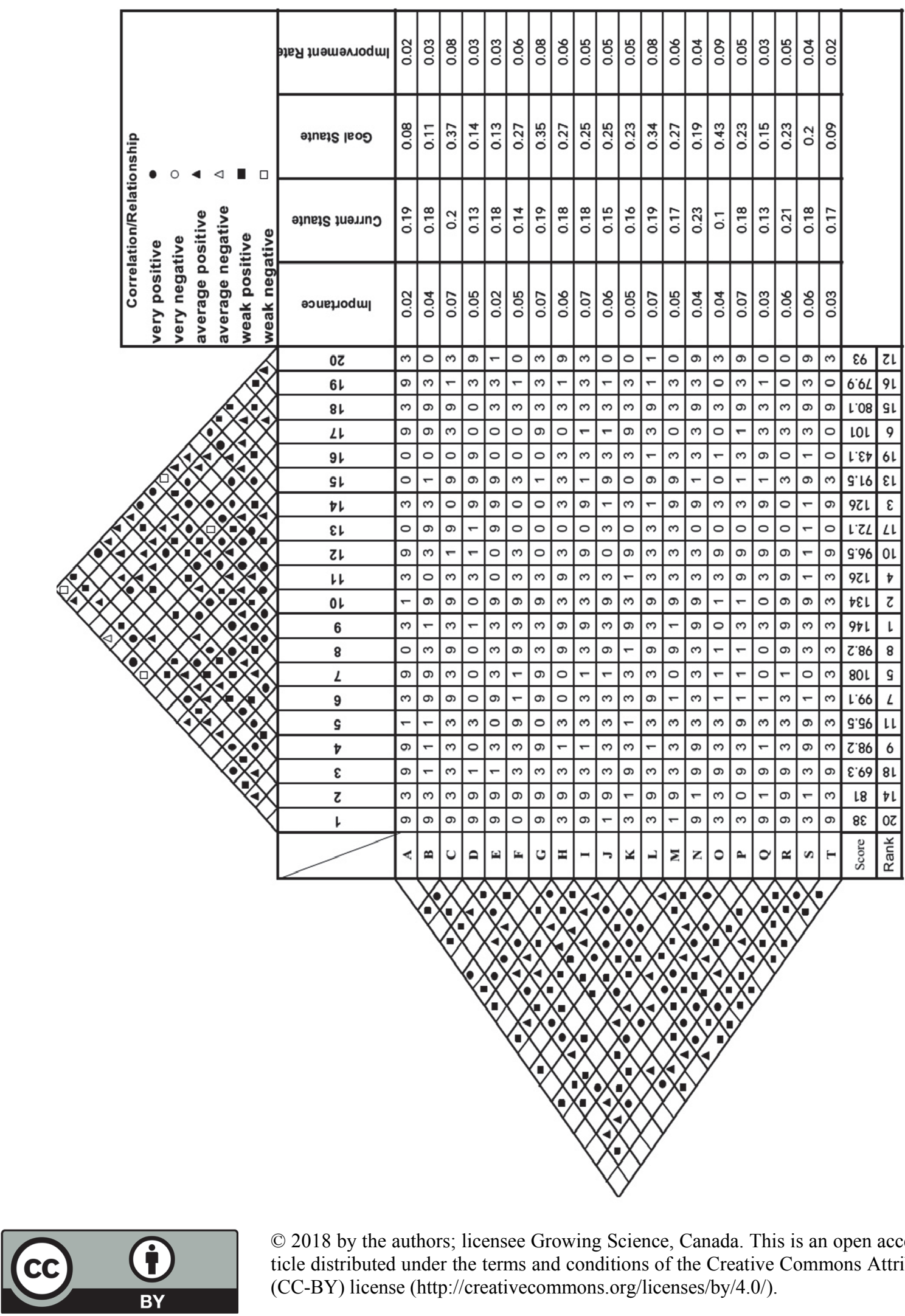

(C) 2018 by the authors; licensee Growing Science, Canada. This is an open access article distributed under the terms and conditions of the Creative Commons Attribution (CC-BY) license (http://creativecommons.org/licenses/by/4.0/). 